\title{
DINAMIKA KOALISI PARTAI-PARTAI POLITIK DI INDONESIA MENJELANG DAN SETELAH PEMILIHAN PRESIDEN TAHUN 2014
}

\author{
R. Widya Setiabudi Sumadinata \\ Departemen Hubungan Internasional, Universitas Padjadjaran \\ E-mail: wsetiabudi@yahoo.com
}

\begin{abstract}
ABSTRAK
Tulisan ini menelaah dinamika koalisi partai-partai politik di Indonesia terutama pada pemilihan presiden tahun 2014 melalui pendekatan logika Fuzzy. Hasil studi ini menunjukkan bahwa ideologi partai politik tidak dapat dijadikan sebagai preferensi koalisi partai politik secara absolut. Terbentuknya koalisi adalah dasar kepentingan politik yang bersifat office seeking. Partai-partai politik di Indonesia belum mampu secara mandiri dalam hal pendanaan partai tetapi mengandalkan sumber dari APBN yang diperoleh melalui anggota-anggotanya di eksekutif maupun legislatif. Namun, pemodelan logika Fuzzy untuk koalisi pada tulisan ini masih sangat sederhana dan perlu diuji lagi rigority dari model matematikanya sehingga dapat menggambarkan kondisi riil dari perilaku partai-partai politik dalam melakukan koalisi.
\end{abstract}

Kata kunci: koalisi, partai politik, dan logika fuzzy

\section{THE DYNAMICS OF POLITICAL PARTIES COALITION IN INDONESIA BEFORE AND AFTER PRESIDENTIAL ELECTION IN 2014}

\begin{abstract}
This paper examines the dynamics of a coalition of political parties in Indonesia, especially in the presidential election of 2014 through a Fuzzy approach. The results of this study indicate that the ideology of political parties cannot be used as coalition preferences in absolute terms. The formation of the coalition is heavily based on seeking office interest. In other words, political parties in Indonesia have not been able to gain funding independently but still rely on state resources that obtained through its members in the executive and legislative offices. However, fuzzy logic modeling to the coalition as conducted in this writing is still very simple and need to test rigor of mathematical models that can describe the real condition of the behavior of political parties to form a coalition.
\end{abstract}

Key words: coalition, political parties, and fuzzy logic

\section{PENDAHULUAN}

Peta aliansi politik Indonesia mengalami perubahan sejak pemilihan presiden tahun 2014 usai. Koalisi partai politik berubah, partai-partai politik yang semula bersikap oposan terhadap pemerintahan Presiden Joko Widodo sebagian beralih menjadi partai pendukung pemerintah. Diawali oleh Partai Persatuan Pembangunan yang menyatakan bergabung dengan koalisi pendukung pemerintah (Koalisi Indonesia Hebat) kemudian diikuti oleh Partai Amanat Nasional dan Partai Golkar, kini Koalisi Merah Putih tinggal terdiri dari Partai Gerindra dan Partai Keadilan Sejahtera. Bahkan secara de facto Koalisi Merah Putih telah bubar menurut
Sekretaris Jenderal Partai Gerindra.

Dalam sistem politik yang bersifat multi partai koalisi adalah sebuah keniscayaan. Dalam perspektif teori pilihan-rasional ada dua pendekatan umum yang menjelaskan mengapa partai-partai politik melakukan koalisi, yaitu office-seeking dan policy-seeking (Laver, 1998). Strom (1990) menambahkan satu perspektif lagi yaitu vote-seeking. Riker (1962) berasumsi bahwa koalisi partai politik didorong oleh hasrat untuk mendapat kekuasaan baik di ranah eksekutif maupun legislatif (office seeking). Partaipartai politik kemudian merumuskan strategi pencapaian kekuasaan tersebut melalui formulasi minimalis yang biasa disebut sebagai Minimal Winning Coalition (WMC). Untuk mencapai posisi mayoritas cukup menguasai $50 \%+1$ kursi 
di parlemen. Dengan demikian target utamanya adalah koalisi dengan partai-partai yang memilik kursi besar, dan tidak merasa perlu untuk melibatkan partai-partai kecil.

Katz dan Mair (2009) lebih lanjut mengemukakan bahwa tujuan utama partai-partai adalah menjaga kepentingan mereka dan untuk itu partai-partai politik besar dengan tanpa mengindahkan kesamaan ideologis dan platform politik dapat berkoalisi guna melanggengkan kepentingan mereka bersama untuk tetap berkuasa, yang kemudian dikenal sebagai cartelparty. Axelroad (1970) kemudian memodifikasi asumsi Riker (1962) ini, partai politik memang memiliki tujuan untuk memperoleh kekuasaan akan tetapi dalam derajat tertentu juga harus mempertimbangkan tercapainya tujuan yang lebih esensial yaitu tercapainya cita-cita yang lebih ideal dalam bentuk kebijakan (policy), sehingga kemudian pendekatan Axelroad in dikenal sebagai policy seeking.

Senada dengan Axelroad, de Swaan (1973) dan de Swaan dan Mokken (1980) mengemukakan bahwa tujuan partai politik adalah sesuatu yang lebih ideal dalam hal ini berbasis kepada ideologi. Maka basis pembentukan koalisi menurutnya adalah ideologi. Kekuasaan hanya alat untuk mencapai tujuan partai yaitu cita-cita ideologis. Ideologi kemudian diterjemahkan ke dalam sesuatu yang bersifat konkrit (platform). Kesamaan platform ini yang kemudian akan mengelompokkan partai-partai politik ke dalam sebuah koalisi.

Dinamika koalisi partai politik di Indonesia menjelang dan sesudah pemilihan preside pada tahun 2014 oleh sebagian sarjana-sarjana politik sebagai manifestasi dari model koalis office-seeking. Karakteristik model koalisi office-seeking bersifat cair, tidak permanen. Ha ini oleh seakan membenarkan adagium politik praktis yang menyatakan bahwa di dalam politik tidak ada teman atau musuh abadi, yang ada adalah kepentingan abdi.

Dalam konteks demokrasi koalisi yang dibangun di atas motif office-seeking dinilai merugikan para konstituennya sendiri. Para elit politik mengingkari kepercayaan konstituen dengan mengubah keberpihakan dari koalis yang memiliki platform yang sama kepada

Perubahan koalisi partai politk

ua tahun pemerintahan Joko Widodo berjalan memang dapat dijelaskan melalui teori koalisi office-seeking, dimana partai-partai politik dari Koalisi Merah Putih yang berpindah haluan menilai bahwa kepentingan partainya tidak akan terakomodasi jika mereka berada di luar lingkaran pemerintah yang berkuasa. Tetapi teori ini tidak menjelaskan bagaimana ideologi sebagai basis koalisi yang sifatnya fundamental (Surbakti, 1992) bisa berubah dari satu ekstrem kepada ekstrem yang lainnya. Selain itu teor ini tidak menjelaskan secara terukur bagaimana perubahan itu terjadi.

Tulisan ini menawarkan alternatif penjelasan terhadap dinamika koalisi partai politil melalui pendekatan logika fuzzy. Penggunaan logika fuzzy ini tidak menolak asumsi teor office-seeking, tetapi melengkapi teori tersebut sehingga memiliki penjelasan yang lebih terukur. Pertanyaan utama yang ingin dijawab tulisan in adalah apakah teori policy-seeking tidak lag berlaku, apakah partai-partai politik sudah tidak lagi memiliki basis ideologi dan platform yang khas sehingga koalisi dapat begitu cair. Dengan menggunakan prinsip umum logika biner maka seolah-olah perubahan koalisi ini merupakan ironi dalam pandangan policy-seeking. Dengan pendekatan logika fuzzy dapat dijelaskan bahwa partai-partai politik tetap memiliki basis ideologi dan platform yang khas meskipun kemudian mereka berkoalisi dengan partai-partai yang .

\section{METODE}

Logika Fuzzy Sebagai Pendekatan Analisis

Logika fuzzy adalah pendekatan teor grup matematika, pertama kali diperkenalkan oleh Zadeh (1965) yang memandang bahwa keanggotaan suatu individu dalam sebuah grup tertentu tidak bersifat biner seperti dinyatakan oleh logika tegas (crips). Pada himpunan tegas (crisp), nilai keanggotaan suatu individu atau item $\mathrm{x}$ dalam suatu himpunan A, yang sering ditulis dengan $\left.\mu_{\mathrm{N}} \mathrm{x}\right]$, memiliki $\mathrm{A}$, yang sering yaitu bernilai $=$ satu (1), yang berarti bahwa suatu item menjadi anggota dalam suatu himpunan, atau bernilai $=$ nol $(0)$, yang berart bahwa suatu item tidak menjadi anggota dalam suatu himpunan. Pada logika fuzzy keanggotaan suatu individu atau item tidak bersifat diskrit dan biner melainkan kontinyu dengan nilai keanggotaan $\mu_{\star}[\mathrm{x}]$ tersebut antara $[0,1]$
Sebagai ilustrasi dapat dilihat penggolongan pada usia manusia. Dalam konteks himpunan crisp, usia dapat dikategorikan ke dalam 3 kategori linguistik "Muda" "Parobaya" "Tua" Dan secara numerik dinyatakan sebagai berikut (Kusumadewi dan Purnomo, 2010)

a) MUDA

B) PAROBAYA

umur $<35$ tahun

c) TUA

$\leq 55$ tahu

Nilai keanggotaan secara grafis, himpunan "Muda", "Parobaya" dan "Tua" ini dapat dilihat pada Gambar 1
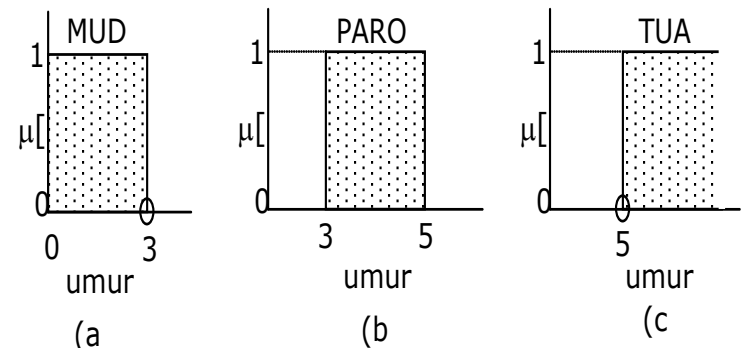

Gambar 1. Himpunan: Muda, Parobaya, Dan Tua.

Pada Gambar 1, dapat dilihat bahwa:

a) apabila seseorang berusia 34 tahun, maka ia dikatakan MUDA $\left(\mu_{\mathrm{MUDA}}[34]=1\right)$;

b) apabila seseorang berusia 35 tahun, maka ia dikatakan TIDAK MUDA $\left(\mu_{\mathrm{MUDA}}[35]=0\right)$;

c) apabila seseorang berusia 35 tahun kurang 1 hari, maka ia dikatakan TIDAK MUDA $\left(\mu_{\text {MUDA }}[35\right.$ th $\left.-1 \mathrm{hr}]=0\right)$;

d) apabila seseorang berusia 35 tahun maka ia dikatakan PAROBAYA $\left(\mu_{\text {PAROBAYA }}[35]=1\right)$;

e) apabila seseorang berusia 34 tahun, maka ia dikatakan TIDAK PAROBAYA $\left(\mu_{\text {PAROBAYA }}[34]=0\right)$;

f) apabila seseorang berusia 35 tahun, maka ia dikatakan PAROBAYA ( $\mu_{\text {a }}[35]=1$ );

) apabila seseorang berusia 35 thun

kurang 1 hari, PAROBAYA $\left(\mu_{\text {PAROBAYA }}[35\right.$ th $\left.-1 \mathrm{hr}]=0\right)$;

Dari sini bisa dikatakan bahwa pemakaian himpunan crisp untuk menyatakan umur sangat tidakadil, adanya perubahan kecil saja pada suatu nilai mengakibatkan perbedaan kategori yang cukup signifikan. Himpunan fuzzy digunakan
untuk mengantisipasi hal tersebut. Seseorang untuk mengantisipasi hal tersebut. Seseorang
dapat masuk dalam 2 himpunan yang berbeda, MUDA dan PAROBAYA, PAROBAYA dan TUA, dsb. Seberapa besar eksistensinya dalam himpunan tersebut dapat dilihat pada nilai keanggotaannya. Gambar 2 menunjukkan himpunan fuzzy untuk variabel umur.

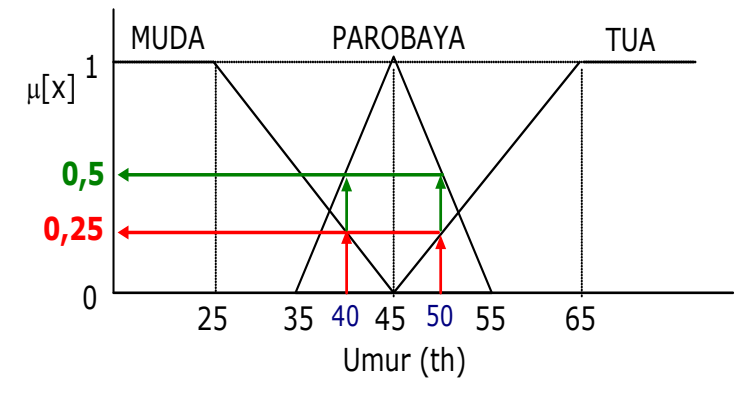

Gambar 2. Himpunan Fuzzy untuk Variabel Umur.

Pada Gambar 2, dapat dilihat bahwa Seseorang yang berumur 40 tahun, ter-masuk dalam himpunan MUDA dengan $\mu_{\text {MUDA }}[40]=$ 0,25 ; namun dia juga termasuk dalam himpunan PAROBAYA dengan $\mu_{\text {PAB }}[40]=0,5$. Seseorang yang berumur 50 tahun, termasuk dalam himpunan MUDA dengan $\mu_{\mathrm{TUA}}[50]=$ 0,25 ; namun dia juga termasuk dalam himpunan PAROBAYA dengan $\mu_{\mathrm{PABOBAYA}}[50]=0,5$.

Kalau pada himpunan crisp, nilai keanggotaan hanya ada 2 kemungkinan, yaitu 0 atau 1, pada himpunan fuzzy nilai keanggotaan terletak pada rentang 0 sampai 1 . Apabila $x$ memiliki nilai keanggotaan fuzzy $\mu_{\mathrm{A}}[\mathrm{x}]=0$ berarti $\mathrm{x}$ tidak menjadi anggota himpunan A, demikian pula apabila $\mathrm{x}$ memiliki nilai keanggotaan fuzzy $\mu_{\mathrm{A}}[\mathrm{x}]=1$ berarti $\mathrm{x}$ menjadi anggota penuh pada him-punan $\mathrm{A}$.

\section{HASIL DAN PEMBAHASAN}

\section{Dinamika Koalisi Partai Politik}

Pada pemilihan presiden Indonesia tahun 1999 terjadi koalisi partai politik di parlemen (Dewan Perwakilan Rakyat) untuk memilih presiden. Yang menarik saat itu adalah koalis dengan basis ideologis seakan-akan terbentuk melalui koalisi "Poros Tengah" yang terdir dari partai-partai Islam yaitu Partai Amanat Nasional(PAN),PartaiPersatuanPembangunan (PPP), Partai Kebangkitan Bangsa (PKB), Partai Bulan Bintang (PBB), Partai Keadilan, Partai Kebangkitan Umat, Partai Nahdlatul Umat, dan PSII. Indikator bahwa koalisi ini berbasis ideologis sebenarnya tidak cukup memadai karena tidak ada cukup alasan yang menunjukkan dasar pencalonan Abdurrahman Wahid sebagai presiden karena pertimbangan 
latar belakang agama. Namun secara formal anggota kelompok Poros Tengah adalah partaipartai berbasis agama Islam. Premis bahwa Poros Tengah adalah koalisi berbasis ideologi diragukan keabsahannya ketika koalisi in mendorong pemakzulan Abdurrahman Wahid sebagai presiden dan menggantikannya dengan Megawati Soekarno Puteri yang sebelumnya berada koalisi yang berbeda.

Pada tahun 2004 presiden Republik Indonesia dipilih secara langsung oleh rakyat. Syarat dan dan tata cara pemilihan presiden langsung diatur oleh Undang-Undang Nomor 23 tahun 2003 tentang Pemilihan Umum Presiden dan Wakil Presiden. Untuk dapat mengajukan calon presiden dan wakil presiden setiap partai politik harus memenuhi ambang batas minima perolehan kursi partai tersebut di parlemen (presidential threshold) yaitu mendapatkan minimal $15 \%$ jumlah kursi di parlemen atau $20 \%$ dari perolehan suara sah secara nasional pada pemilihan umum legislatif. Dengan jumlah partai peserta pemilihan umum yang lebih daripada 2 buah (multipartai) maka koalisi atau gabungan partai-partai menjadi suatu keniscayaan.

Berdasarkan hasil perolehan pemilihan legislatif pada tahun 2004 partai-partai politik harus berkoalisi untuk dapat mengusung calon pasangan presiden dan wakil presidennya. Koalisi berbasis ideologis seperti yang dibuat oleh Poros Tengah pada pemilihan presiden di parlemen pada tahun 1999 tidak terjadi. Partai-partai berbasis keagamaan seperti PKB, PPP, PBB, PAN dan PKS masing-masing mengusung calon

presiden. Hasilnya tidak ada pasangan calon presiden dan wakil presiden yang menang secara mayoritas, sehingga pemilihan harus dilakukan dua putaran. Pada putaran kedua inila koalisi partai-partai politik kembali berubah, basis ideologis sebagai dasar koalisi semakin memudar. Pada pemilihan umum presiden tahun 2009 presidential threshold berubah kembali menjadi minimal 20\% dari jumlah kursi DPR atau memperoleh $25 \%$ (dua puluh lima persen) dari suara sah masional dalam pemilu ango DPR Koalisi parti Islum DPR. Kolisi partai Islam yang diwakili ole PKS, PAN, PKB, dan PPP seolah-olah kembal muncul ketika bersama dengan Partai Demokrat yang nasional dan 19 partai politik lainnya mengusung pasangan calon presiden dan waki presiden Susilo Bambang Yudhoyono dan Boediono. Di kubu yang berbeda, PD Boediono. Di kubu yang berbeda, PDIP yang dalam menggalang koalisi yang diindikasikan dengan mitra koalisinya Partai Gerindra yang juga berbasis ideologi nasionalis. Pemilihan presiden tahun 2014 semakin menunjukkan asumsi bahwa basis ideologis tidak lagi relevan dijadikan rujukan koalisi partai politik.

\section{Analisis Logika Fuzzy Terhadap Koalis}

\section{Dinamika Koalisi Partai-Partai Politik}

Perubahan koalisi partai politik dapa dipahami melalui pendekatan logika fuzzy. Keterikatan partai-partai politik terhadap variabelvariabel yang menentukan koalisi dapat dinilai dalam fungsi keanggotaannya dalam variabelvariabel tersebut. Dinamika koalisi partai politik pada pemilihan presiden sejak tahun 1999 hing-

Tabel 1. Tipologi Partai Politik Menjelang Pemilihan Presiden Tahun 2014

\begin{tabular}{|c|c|c|c|c|c|c|}
\hline Nama Partai & Ideologi & $\begin{array}{l}\text { Pilpres } \\
1999\end{array}$ & $\begin{array}{l}\text { Pilpres } \\
2004\end{array}$ & $\begin{array}{l}\text { Pilpres } \\
2009\end{array}$ & $\begin{array}{l}\text { Sebelum } \\
\text { Pilpres } \\
2014\end{array}$ & $\begin{array}{c}\text { Setetlah } \\
\text { Pilpres } 204\end{array}$ \\
\hline Gerindra & Nasionalis & - & - & Mega-Prabowo & KMP & KMP \\
\hline PKS & Islam & - & Amin Rais & SBY-Boediono & KMP & KMP \\
\hline Golkar & Nasionalis & "netral" & $\begin{array}{l}\text { Wiranto- } \\
\text { Salahudin }\end{array}$ & JK- Wiranto & KMP & KIH \\
\hline PBB & Islam & Poros Tengah & SBY-JK & SBY-Boediono & KMP & $\mathrm{KIH}$ \\
\hline PAN & Islam & Poros Tengah & Amin Rais & SBY-Boediono & КMP & $\mathrm{KIH}$ \\
\hline PPP & Islam & Poros Tengah & Hamzah Haz & SBY-Boediono & KMP & KIH \\
\hline PDIP & Nasionalis & Nasionalis & $\begin{array}{l}\text { Mega- } \\
\text { Hasyim }\end{array}$ & Mega-Prabowo & $\mathrm{KIH}$ & $\mathrm{KIH}$ \\
\hline PKB & Islam & Poros Tengah & $\begin{array}{l}\text { Mega- } \\
\text { Hasyim }\end{array}$ & SBY-Boediono & KIH & $\mathrm{KIH}$ \\
\hline Demokrat & Nasionalis & - & SBY-JK & SBY-Boediono & "netral" & "netral" \\
\hline Hanura & Nasionalis & - & - & JK- Wiranto & "netral" & "netral" \\
\hline Nasdem & Nasionalis & - & - & - & KIH & KIH \\
\hline
\end{tabular}

ga tahun 2014 berdasarkan ideologinya adalah sebagai berikut:

Merujuk kepada berbagai teori tentang ideologi dan politik aliran dari partai-partai politik di Indonesia maka secara garis besar dapat dikelompokkan kepada dua kategori "nasionalis" dan "religius (islam)". Maka jika dilihat dari dinamika yang terjadi memetakan pengelompokkan atau koalisi partai-partai politik di Indonesia seperti terlihat pada tabel di atas dapat dikatakan bahwa referensi ideologis sebagai pertimbangan pembentukan koalisi tidak bersifat biner. Keanggotaan koalisi berdasarkan ideologi terlihat pada pemilihan presiden tahun 1999, dimana ada dua kubu yaitu "poros tengah" yang terdiri dari partai-partai Islam dan kubu nasionalis yaitu Partai Demokrasi Indonesia Perjuangan (PDIP).

Pada pemilihan presiden tahun 2004 koalisi Islam terpecah menjadi kubu "Amin Rais" yang terdiri dari dua partai Islam yaitu PAN dan PKS serta koalisi "Islam-nasionalis" yang diindikasikan oleh koalisi PKB dengan Golkar dan PKB dengan PDIP. Pada masa ini koalisi PAN dan PKS dapat dikatakan masih mewakili pembentukan koalisi berdasarkan ideologi (Islam) sebagaimana pada tahun 1999 dengan pembentukan "Poros Tengah".

Pada pemilihan presiden tahun 2009 koalisi partai Islam seperti bersatu kembali ketika sepakat mendukung pasangan SBY-Boediono, sedangkan koalisi partai-partai nasionalis justru terpecah dengan membentuk dua koalisi berbeda yaitu Golkar-Hanura serta PDIP-Gerindra. Dan pada pemilihan presiden tahun 2014 dinamika koalisi partai-partai politik menunjukkan bahwa pengelompokan koalisi berdasarkan ideologi tidak dilaksanakan secara konsisten. Menjelang pemilihan presiden partai-partai Islam seperti hendak membentuk "Koalisi Poros Tengah Baru" dengan mengkombinasikan model koalisi partai Islam pada pemilihan presiden tahun 1999 dan tahun 2009, tetapi setelah pemilihan presiden berlangsung koalisi tersebut tidak berjalan dan cenderung menunjukkan bahwa pertimbangan ideologi tidak lagi penting.

Dalam konteks logika Fuzzy keanggotaan koalisi berdasarkan ideologis memiliki fungsi keanggotaan yang mengikuti logika Fuzzy, artinya tidak diskrit dan biner melainkan kontinyu. Jika merujuk pada persamaan sebelumnya maka fungsi keanggotaan koalisi partai politik berdasarkan ideologi dapat digambarkan sebagai berikut.

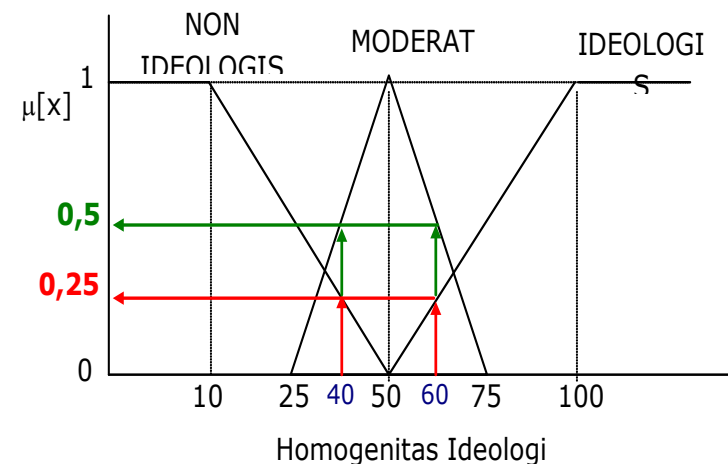

$(\%)$

Gambar 3. Himpunan Fuzzy Untuk Variabe Homogenitas Ideologi Koalisi.

Pada Gambar 3. dapat dilihat bahwa jika sebuah partai politik yang tergabung dalam suatu koalisi dimana $40 \%$ anggotanya merupakan partai-partai yang memiliki kesamaan ideologis, termasuk dalam himpunan NON IDEOLOGIS dengan $\mu_{\text {voNo }}[40]=0,25$; namun dia juga termasuk dalam himpunan MODERAT dengan $\mu_{\text {MODERAT }}[40]=0,5$. Sebuah partai politik yang tergabung dalam suatu koalis dimana $60 \%$ anggotanya merupakan partaipartai yang memiliki kesamaan ideologis, termasuk dalam himpunan NONIDEOLOGIS dengan $\mu_{\text {NONIDEOLOGIS }}[60]=0,25$; namun dia juga termasuk dalam himpunan MODERAT dengan $\mu_{\text {MODERAT }}[60]=0,5$.

\section{SIMPULAN}

Dari penjelasan di atas dapat disimpulkan bahwa ideologi tidak dapat dijadikan sebaga preferensi koalisi partai politik secara absolut. Karena terbukti bahwa komposisi koalisi tidak selalu dibentuk atas dasar ideologi. Penjelasan yang lebih sering dikemukakan para analis untuk menjelaskan terbentuknya koalisi adalah dasar kepentingan politik yang bersifat non ideologis atau office seeking. Partai-partai politik di Indonesia belum mamp secara mandiri dalam hal pendanaan partai, selama ini sumber pendapatan partai terbesar adalah dari APBN yang diperoleh melalui anggota-anggota partai politik yang menduduki jabatan eksekutif maupun legislatif melalui berbagai modus, misalnya institutional fee dari anggaran suatu proyek dimana lembaga tempa proyek tersebut berada dikuasai oleh kader 
partai tersebut. Partai-partai politik tidak tahan untuk bersikap oposisi terhadap pemerintah yang berkuasa karena untuk mendapatkan akses kepada APBN maka harus ada kader partai politik yang menduduki jabatan struktural di lembaga tempat proyek yang didanai APBN tersebut. Pemodelan logika Fuzzy untuk koalisi pada tulisan ini masih sangat sederhana, perlu diuji lagi rigority dari model matematikanya sehingga dapat menggambarkan kondisi riil dari perilaku partai-partai politik dalam melakukan koalisi.

\section{DAFTAR PUSTAKA}

Axelrod, R. (1970). Conflict of Interest. Chicago: Markham.

de Swaan, A. \& R. J. Mokken. (1980). Testing coalition theories: The combined evidence, in: L. Lewin and E. Vedugn (eds.), Politics as Rational Action. Dordrecht: Reidel.

de Swaan, A. (1973). Coalition Theories and Cabinet Formations. Amsterdam: Elsevier. de Swaan, Abram. (1973). Coalition Theories and Cabinet Formation. Amsterdam: Elsevier.

Katz, R.S. andMair,P.(2009). 'The Cartel Party Thesis: A Restatement', Perspectives on Politics, 7(4), pp. 753-766. doi: $10.1017 / \mathrm{S} 1537592709991782$.

Kusumadewi, S. dan Purnomo. (2010). Aplikasi Logika Fuzzy UntukMendukung Keputusan. Yogyakarta: Graha Ilmu.

Laver, M. (1998). Models of government formation. Annual Review of Political Science 1: 1-25.

Riker, William. (1962). The Theory of Political Coalitions. New Haven: Yale University Press.

Strom, Kaare. (1990). Minority Government and Majority Rule. Cambridge: Cambridge University Press.

Surbakti, Ramlan. (1992). Memahami Ilmu Politik. Jakarta: PT Grasindo.

Zadeh, Lotfi A. Fuzzy Set. "Fuzzy Sets". Information and Control, 8:338-353, 1965. 